\title{
Pratik Diyetlerde Balık Unu Yerine Kısmen Gülibrişim (Albizia julibrissin) Tohumu Unu Kullanılmasının Koi Sazan (Cyprinus carpio) Yavrularının Gelişimi Üzerine Etkisi*
}

\author{
Ertuğrul KİREÇCí**, Mehmet ORUÇ, Hakan Murat BÜYÜKÇAPAR
}

KSÜ, Ziraat Fakültesi Su Ürünleri Bölümü, Kahramanmaraş

Geliş Tarihi (Received) : 10.11.2014

Kabul Tarihi (Accepted) : 05.12.2014

\begin{abstract}
Özet: Gülibrişim (Albizia julibrissin) tohumu ununun koi sazanı (Cyprinus carpio) yavrularının pratik diyetlerinde protein kaynağı olarak kullanılabilirliğini belirlemek için laboratuar koşullarında, 60 günlük besi denemesi yürütülmüştür. Gülibrişim tonumu unu diyetlere $\% 0,10,20,30,40$ oranında katılmıştır $\left(\mathrm{D}_{0}, \mathrm{D}_{1}, \mathrm{D}_{2}, \mathrm{D}_{3}, \mathrm{D}_{4}\right) . \mathrm{Bu}$ diyet grupları büyüme parametreleri bakımından balık unu ve soya fasulyesi unu ağırlıklı diyetle beslenen kontrol grubuyla karșılaştııılmıştır. Denemede büyüme parametreleri bakımından $\mathrm{D}_{1}, \mathrm{D}_{2}$ diyet grupları ile $\mathrm{D}_{0}$ grupları arasında fark benzer bulunurken $(\mathrm{P}>0.05), \mathrm{D}_{0}$ grubu diğer gruplara göre önemli derecede yüksek bulunmuştur $(\mathrm{P}<0.05)$. Gülibrişim (Albizia julibrissin) tohumu unu koi sazanı (Cyprinus carpio) diyetlerine \%20'ye kadar herhangi bir istenmeyen etkisi olmaksızın katılabilir.
\end{abstract}

Anahtar kelimeler: Gülibrişim, Albizia julibrissin, Koi sazanı, Cyprinus carpio, Büyüme

\section{Effect of Partially Replacing Fish Meal with Honey Silk Tree (Albizia julibrissin) on Growth Composition of} Koi Carpo (Cyprinus carpio), Fingerlings, in Practical Diets

\begin{abstract}
A 60 day laboratory growth trial was carried out to determine the potential nutritional value of silktree (Albizia julibrissin) seed as a dietary protein source of koi carp (Cyprinus carpio) fingerlings. Silk tree (Albizia julibrissin) seed was included in the diets at different levels $\% 0,10,20,30,40\left(\mathrm{D}_{0}, \mathrm{D}_{1}, \mathrm{D}_{2}, \mathrm{D}_{3}\right.$, and $\mathrm{D}_{4}$ respectively) and the growth parameters of fish feed these diets were compared to fish feed a fish meal and soybean meal based $\mathrm{D}_{0}$ diet. On the basis of the observed growth parameters $\mathrm{D}_{0}, \mathrm{D}_{1}, \mathrm{D}_{2}$ diets were similarly $(\mathrm{P}>0.05)$. But $\mathrm{D} 0$ were significantly $(P<0.05)$ higher those fed on the other groups $\left(\mathrm{D}_{3}, \mathrm{D}_{4}\right)$. Silk Tree (Albizia julibrissin) seed can be used up to \%20 of diet as protein source in diets of koi carp (Cyprinus carpio) without any adverse effects.
\end{abstract}

Key Words: Silk Tree, Albizia julibrissin, Koi carp, Cyprinus carpio, Growth

\section{GİRIŞ}

Doğadan yakalanan ve ekonomik değeri olmayan balık türlerinden elde edilen balık ununun son 10 yıldır dünya genelinde üretimi y1llı 6.5 milyon ton civarındadır. 2015 yılında üretilen balık ununun $\% 50$ ‘si ile balık yağının \%88'inin akuakültür yemlerinde kullanılacağ 1 tahmin edilmektedir (Pike ve Barlow, 2003). Ancak son yıllarda balık stoklarının azalması ve daha çok insan beslenmesinde kullanılması nedeniyle balık unu üretimi azalmış, yem üreticileri dışarıdan balık unu ithal etmeye başlamıştır. Dolayısıyla balık unu fiyat1, buna paralel olarak yem maliyeti artmış ve bitkisel kaynakların kullanımı gündeme gelmiştir. Bu bağlamda yem maliyetini azaltmak, balık unu yerine kullanılabilecek alternatif protein kaynakları ve kullanım koşullarını belirlemek amacıyla çeşitli çalışmalar yürütülmektedir (Akiyama ve ark., 1995).

Balık yemlerinde en yaygın kullanılan bitkisel protein kaynaklarından birisi de baklagillerdir. Baklagiller besin maddesi içerikleri bakımından buğdaygillerden oldukça farklı bir yapıdadırlar. Baklagil tohumlarının en önemli özellikleri buğdaygil tohumlarına göre, protein ve yağ içerikleri bakımından çok daha zengin olmalarıdır, yaklaşık \%20-45 arasında protein içerirler (Ertaş, 2007). Çeşitli balık diyetlerine baklagil tohumu katılarak yapılan bazı çalışmalar aşağıdaki gibi özetlenebilir. Sesbania aculeata (Hossain ve ark., 2002), bezelye (Pisum sativum) (Borlongan ve ark., 2003), (Büyükçapar ve ark., 2010), Cassia fisculata (Adebayo ve ark., 2004), culban (Vicia peregrina) (Buyukcapar ve Kamalak, 2006), bezelye (Pisum sativum) (Overland ve ark., 2009), kırmızı mercimek (Lens culinaris) (Ustaoğlu ve ark., 2009), 121 ${ }^{\circ} \mathrm{C}$ 'de 10-30 dk. 1sıtılmış culban (Vicia peregrina) (Büyükçapar, 2012)

$\mathrm{Bu}$ araştırma ülkemizde yaygın olarak bulunan gülibrişim (Albizia julibrissin) tohumunun koi sazan diyetlerine eklenebilecek en uygun dozun belirlenmesi amacıyla yapılmıştır.

\section{MATERYAL ve METOT}

\section{Diyet Hazırlama}

Gülibrişim (Albizia julibrissin) tohumu Avşar yerleşkesi bahçesinden eylül ayının ilk haftası toplanılarak temin edilmiştir. Toplanan tohumlar gölgede kurutulduktan sonra $1 \mathrm{~mm}$ elekten geçecek şekilde öğütülerek un haline getirilmiştir. Diyetlere gülibrişim tohumu ham olarak $(\% 0,10,20,30,40)$ katılmıştır. Gülibrişim tohumu, balık unu soya küspesi ve misır ununun kimyasal kompozisyonları Çizelge 1 'de, deneme rasyonları ise Çizelge 2'de verilmiştir.

\footnotetext{
* Bu çalışma KSÜ BAP tarafindan desteklenen 2013/5-2 nolu yüksek lisans projesinden elde edilmiştir.

** Sorumlu yazar: Kireçci, E., , tekno2_@ @hotmail.com
} 
Gülibrişim tohumunun aminoasit ve yağ asidi içerikleri Çizelge 3'deki gibidir.

Çizelge 1. Karma yemlere katılan gülibrişim (Albizia julibrissin), balık unu, mısır unu ve soya ununun kuru maddedeki kimyasal kompozisyonu

\begin{tabular}{lllll}
\hline \multicolumn{1}{c}{ Besin Birleşenleri $(\mathrm{g} / \mathrm{kg})$} & \multicolumn{1}{c}{ Balık unu } & Soya unu & Misır unu & Gülibrişim \\
\hline Ham Protein & 663.6 & 470.0 & 78.0 & 300 \\
Ham Yăg & 109.3 & 10.0 & 35.2 & 22.5 \\
Ham Kül & 135.0 & 60.0 & 55.2 & 48.1 \\
Ham Selüloz & 5.0 & 60.0 & 26.2 & 82.1 \\
Kuru Madde & 900.6 & 890.4 & 881.3 & 890 \\
Toplam enerji $(\mathrm{MJ} / \mathrm{kg})^{*}$ & 21.3 & 17.5 & 16.21 & 18.4 \\
\hline
\end{tabular}

*Hesaplanmış değer; toplam enerji balık unu için $23.6 \mathrm{kj} / \mathrm{g}$, ham yăg için $39.5 \mathrm{kj} / \mathrm{g}$ ve karbonhidrat için ise 17.2 $\mathrm{kj} / \mathrm{g}$ değerlerinden yararlanarak hesaplanmıştır.(NRC,1993)

Denemede kullanılan rasyonların enerji ve protein oranları dengelenmiştir. Rasyonları oluşturan bütün birleşenler mikserde karıştırıldıktan sonra \%30 su katılarak hamur haline getirilmiş olup et makinesinin 2 no'lu eleğinden geçirilerek pelet haline getirilen diyetler $55^{0} \mathrm{C}^{\prime}$ de 12 saat etüvde kurutulmuştur. Kontrol diyetinde ana protein kaynağ $\breve{1}_{1}$ olarak $\% 35$ oranında balık unu ve \%25 oranında soya küspesi kullanılmıștır. Balıklar tartım ve ölçüm yapmadan bir gün önce aç bırakılmış olup 20 günlük arayla diyet gruplarındaki bütün balıkların ağırlıkları tartılmıştır.

Çizelge 2. Deneme rasyonlarının formülasyonu ve besin bileşenleri

\begin{tabular}{|c|c|c|c|c|c|}
\hline \multirow[t]{2}{*}{ Diyet birleşenleri $(\mathrm{g} / \mathrm{kg})$} & $\mathrm{D}_{0}$ & $\mathrm{D}_{1}$ & $\mathrm{D}_{2}$ & $\mathrm{D}_{3}$ & $\mathrm{D}_{4}$ \\
\hline & $\% 0$ & $\% 10$ & $\% 20$ & $\% 30$ & $\% 40$ \\
\hline Balık unu & 350 & 315 & 280 & 245 & 215 \\
\hline Soya unu & 250 & 250 & 250 & 250 & 250 \\
\hline Gülibrişim & 0 & 100 & 200 & 300 & 400 \\
\hline Misir unu & 321 & 253 & 191 & 126 & 56 \\
\hline Ayçiçeği yağı & 68 & 68 & 68 & 68 & 68 \\
\hline $\mathrm{DCP}^{1}$ & 1 & 1 & 1 & 1 & 1 \\
\hline Vit-Min ${ }^{2}$ & 6 & 6 & 6 & 6 & 6 \\
\hline Mermer tozu & 1 & 1 & 1 & 1 & 1 \\
\hline Tuz & 1 & 1 & 1 & 1 & 1 \\
\hline Methionine & 1 & 1 & 1 & 1 & 1 \\
\hline Lysine & 1 & 1 & 1 & 1 & 1 \\
\hline Toplam & 1000 & 1000 & 1000 & 1000 & 1000 \\
\hline \multicolumn{6}{|l|}{ Besin birleşenleri } \\
\hline Ham protein & 388 & 389 & 392 & 389 & 393 \\
\hline Ham yağ & 127.235 & 124.544 & 121.853 & 119.162 & 119.162 \\
\hline Ham selüloz & 22.918 & 26.208 & 29.489 & 32.788 & 32.788 \\
\hline Ham kül & 46.1 & 43.2 & 45.2 & 48.3 & 47.3 \\
\hline Kuru madde & 880.1 & 882.3 & 883.2 & 892.2 & 893.3 \\
\hline Toplam Enerji $(\mathrm{MJ} / \mathrm{kg})^{3}$ & 19.676 & 19.536 & 19.421 & 19.256 & 19.141 \\
\hline
\end{tabular}

${ }^{1}$ Di kalsiyum Fosfat

${ }^{2}$ Her 5kg'da bulunan vitamin mineral içerikleri 200.000.000 IU vitamin A, IU vitamin D3, 200.000 mg vitamin E, $12,000 \mathrm{mg}$ vitamin $\mathrm{K}_{3}, 20.000 \mathrm{mg}$ vitamin B1, $30.000 \mathrm{mg}$ vitamin B2, $200.000 \mathrm{mg}$ niyasin, $50.000 \mathrm{mg}$ Capanthothenate, $20.000 \mathrm{mg} \mathrm{B} 6,50 \mathrm{mg}$ vitamin B12, $50 \mathrm{mg}$ vitamin B12, $500 \mathrm{mg}$ D-biotin, 1,200 mg folik asit, $200.000 \mathrm{mg}$ vitamin $\mathrm{C}$ ve $300.000 \mathrm{mg}$ inositol, $1.200 .000 \mathrm{mg}$ cholin chloride, $40.000 \mathrm{mg}$ mangan, $30.000 \mathrm{mg}$ Çinko, $800 \mathrm{mg}$ Bakır, $1.000 \mathrm{mg}$ iyodin, $150 \mathrm{mg}$ selenyum, $40.000 \mathrm{mg}$ magnezyum bulunmaktadır.

${ }^{3}$ Hesaplanmış değer; toplam enerji balık unu için $23.6 \mathrm{kj} / \mathrm{g}$, ham yağ için $39.5 \mathrm{kj} / \mathrm{g}$ ve karbonhidrat için ise 17.2 $\mathrm{kj} / \mathrm{g}$ değerlerinden yararlanarak hesaplanmıştır. (NRC,1993) 
Çizelge 3. Gülibrişim tohumunun aminoasit ve yağ asidi içerikleri

\begin{tabular}{llll}
\hline Esansiyel Aminoasitler & $(\mathrm{g} / \mathrm{kg})$ & Esansiyel Yă̆ asitleri & $\%$ \\
\hline Fenilalanin & 14.07 & $\mathrm{C} 20: 4 \mathrm{n}-6$ & 0.111 \\
Histidin & 14.12 & $\mathrm{C} 16: 1 \mathrm{n}-7$ & 0.413 \\
İzolöysin & 12.51 & $\mathrm{C} 18: 1 \mathrm{n}-9$ & 15.77 \\
Löysin & 25.45 & $\mathrm{C} 18: 2 \mathrm{n}-6$ & 63.718 \\
Metiyonin & 3.97 & $\mathrm{C} 18: 3 \mathrm{n}-6$ & 0.08 \\
Treonin & 5.62 & $\mathrm{C} 20: 1 \mathrm{n}-9$ & 0.094 \\
Lizin & 32.57 & $\mathrm{C} 20: 3 \mathrm{n}-3$ & 0.283 \\
Valin & 12.44 & $\mathrm{C} 20: 5 \mathrm{n}-3$ & 0.438 \\
& & $\mathrm{C} 24: 1 \mathrm{n}-9$ & 0.115 \\
\hline Esansiyel Olmayan Aminoasitler & $(\mathrm{g} / \mathrm{kg})$ & Esansiyel Olmayan Yağ asitleri & $\%$ \\
\hline Alanin & 15.40 & $\mathrm{C} 14: 0$ & 0.065 \\
Aspartik & 30 & $\mathrm{C} 15: 0$ & 0.024 \\
Prolin & 12.72 & $\mathrm{C} 17: 1$ & 0.049 \\
Glutamik & $\mathrm{C} 23: 0$ & 0.031 \\
Serin & 19.08 & $\mathrm{C} 16: 0$ & 8.841 \\
Glisin & 3.52 & $\mathrm{C} 17: 0$ & 0.068 \\
& 18.35 & $\mathrm{C} 18: 0$ & 4.505 \\
& & $\mathrm{C} 20: 0$ & 0.170 \\
& & $\mathrm{C} 22: 0$ & 0.109 \\
\hline
\end{tabular}

\section{Balık ve akvaryum sistemleri}

Araștırmada kullanılacak sazan yavruları özel bir balık üretim tesisinden (Adana) KSÜ Ziraat Fakültesi $\mathrm{Su}$ Ürünleri Bölümü'ne oksijen basılmış taşıma poşetleri ile transfer edilmiștir. İșletmeden getirilen koi sazanı yavruları öncelikle \%10'luk metilen mavisinde parazitten arındırılmıştır. Getirilen balıklar ortalama 4 g'dan $6.5 \mathrm{~g}$ olana kadar 250 lt'lik fiberglas tanklarda tutulmuştur. Deneme başlangıcından 7 gün önce balıklar tanklardan alınmıș boy ve ağırlık ölçümleri yapılarak 80lt'lik akvaryumlara yerleştirilmiştir. Deneme 2 yinelemeli 5 diyet grubundan oluşmuştur. Balıklar 15 gün boyunca kontrol diyetiyle beslenmiş ve adaptasyonları sağlanmıștır. $\mathrm{Bu}$ süre içinde hasta ve ölen akvaryumdan uzaklaştırılmıştır. Deneme 60 gün planlanmış olup balıklar vücut ağırlıklarının \%3’ü oranında doyuncaya kadar beslenmiştir. Deneme başlangıcındaki ağırlıkları yaklaşık $6.5 \mathrm{~g}$ olan balıklardan her akvaryuma 10 adet yerleştirilmiştir ve 20 günde bir tartım yapılarak vücut ağırlığına göre verilen yem miktarı artırılmıştır. Akvaryumlarda havalandırma hava motoru ile merkezi olarak sağlanmış, hava hortumu ile eşit dağıtılmıştır. Balıkların konulduğu akvaryumlardaki suyun \%50'si ve kullanılan filtreler 10 günde bir değiştirilip temizlenmiştir. Akvaryumlarda su kalitesi iç ve diş filtrelerle kontrol altında tutulmuş olup günlük sıcaklık ve oksijen oranları ölçülüp, pH oranları ise haftalık olarak ölçülmüştür.

\section{Yemleme zaman}

Balıklar günlük 9:00 ve 17:00 saat arasında balıklar doyuncaya kadar vücut ağırlıklarının \%3’ü kadar beslenmiştir.

\section{Kimyasal Analizler}

Gülibrişim tohumu ve diğer besin maddelerinin kimyasal kompozisyonları AOAC (1990)'a göre yapılmıștır. Gülibrișim tohumunun aminoasit ve yağ asidi analizleri TUBİTAK MAM tarafından yapılmıştır.

\section{Hesaplamalar}

Deneme bitiminde elde edilen büyüme parametreleri ve yem dönüşüm oranlarına ilişkin değerlerin hesaplamasında kullanılan formüller aşağıda verilmiştir. Canlı ăğrlık artışı $(g)=$ Deneme sonu canlı ăğlrlık $(g)$ Deneme başlanglcı canlı ăgrılık (g)

SGR (Spesifik Büyüme Oranı) =ln periyot sonu ağırlık (g) - ln periyot başı ăgırlık (g) / yemlenen gün sayısı) $\mathrm{X}$ 100

YDO (Yem Dönüşüm Oranı) = Tüketilen yem miktarı $(g)$ / Canlı ăgırlık artışı (g)

PER (Protein etkinlik oranı) $=$ Canlı ağırlık artışı $(g)-$ Yemle alınan protein

Kondisyon Faktörü $=\left[\right.$ Ăglrlık $\left.(g) /(\text { Total boy })^{3}(\mathrm{~cm})\right] \mathrm{X}$ 100

Denemeye ait araştırma verileri,"Varyans analizi" ve "Duncan çoklu karıştırma testi"nde 0,05 önem düzeyine göre değerlendirilmiş olup söz konusu istatistiksel analizler SPSS paket programında yapılmıştır.

\section{BULGULAR ve TARTIŞMA}

Deneme boyunca ölçülen oksijen (mg/It), sıcaklık $\left({ }^{\circ} \mathrm{C}\right)$ ve $\mathrm{pH}$ değerleri ortalama değerleri verilmiş olup sirasiyla oksijen $7.3 \pm 0.02-7.4 \pm 0.09 \mathrm{mg} / \mathrm{It}$, sicaklık $23.2 \pm 0.02-23.6 \pm 0.08{ }^{\circ} \mathrm{C}$ ve $\mathrm{pH} 7.62 \pm 0.02-7.94 \pm 0.08$ arasında değişmiştir.

Çalışmada elde edilen, deneme sonu itibariyle ortalama canlı ağırlık kazancı, spesifik büyüme oranı ve yem değerlendirme oranı, protein etkinlik oran1, kondisyon faktörü Çizelge 4'de gösterilmiştir. 
Çizelge 4. Deneme sonu itibariyle canlı ağırlık kazancı, spesifik büyüme oranı yem değerlendirme oranı, protein etkinlik ve kondisyon faktörü

\begin{tabular}{llllll}
\hline & $\mathrm{D}_{0} \% 0$ & $\mathrm{D}_{1} \% 10$ & $\mathrm{D}_{2} \% 20$ & $\mathrm{D}_{3} \% 30$ & $\mathrm{D}_{4} \% 40$ \\
\hline Başlangıç ağrılığı $(\mathrm{g})$ & $6.77 \pm 0.5^{\mathrm{a}}$ & $6.63 \pm 0.4^{\mathrm{a}}$ & $6.74 \pm 0.3^{\mathrm{a}}$ & $6.54 \pm 0.2^{\mathrm{a}}$ & $6.59 \pm 0.3^{\mathrm{a}}$ \\
Final ağırlı̆̆ $(\mathrm{g})$ & $30.15 \pm 1.8^{\mathrm{a}}$ & $28.26 \pm 1.7^{\mathrm{a}}$ & $26.76 \pm 1.8^{\mathrm{a}}$ & $22.52 \pm 1.6^{\mathrm{b}}$ & $21.00 \pm 1.9^{\mathrm{b}}$ \\
Ağırlık kazancı $(\mathrm{g})$ & $23.08 \pm 1.4^{\mathrm{a}}$ & $21.63 \pm 1.5^{\mathrm{a}}$ & $20.02 \pm 1.4^{\mathrm{a}}$ & $15.98 \pm 1.6^{\mathrm{b}}$ & $14.41 \pm 1.1^{\mathrm{b}}$ \\
Yem alımı (g) & $24.6 \pm 1.2^{\mathrm{a}}$ & $26.4 \pm 1.2^{\mathrm{a}}$ & $26.3 \pm 1.3^{\mathrm{a}}$ & $27.5 \pm 1.5^{\mathrm{b}}$ & $26.3 \pm 1.5^{\mathrm{a}}$ \\
YDO & $1.064 \pm 0.1^{\mathrm{a}}$ & $1.223 \pm 0.2^{\mathrm{a}}$ & $1.312 \pm 0.1^{\mathrm{a}}$ & $1.727 \pm 0.2^{\mathrm{b}}$ & $1.827 \pm 0.2^{\mathrm{b}}$ \\
PER (\%) & $2.774 \pm 0.1^{\mathrm{a}}$ & $2.818 \pm 0.2^{\mathrm{a}}$ & $2.568 \pm 0.1^{\mathrm{ab}}$ & $2.643 \pm 0.3^{\mathrm{ab}}$ & $2.172 \pm 0.1^{\mathrm{ab}}$ \\
SGR (\%) & $2.487 \pm 0.2^{\mathrm{a}}$ & $2.414 \pm 0.3^{\mathrm{a}}$ & $2.285 \pm 0.2^{\mathrm{ab}}$ & $2.263 \pm 0.4^{\mathrm{ab}}$ & $1.931 \pm 0.2^{\mathrm{b}}$ \\
Kondisyon Faktörü $(\%)$ & $1.499 \pm 0.2^{\mathrm{a}}$ & $1.550 \pm 0.3^{\mathrm{ab}}$ & $1.514 \pm 0.3^{\mathrm{ab}}$ & $1.465 \pm 0.4^{\mathrm{ab}}$ & $1.404 \pm 0.5^{\mathrm{b}}$ \\
\hline
\end{tabular}

Her satırda aynı harfle gösterilen ortalamalar statiksel olarak benzerdir $(\mathrm{P}>0.05)$.

Deneme süresince balıklarda yemden kaynaklanan herhangi bir ölüm ve yem reddetme olayı gözlenmemiştir. Başlangıçta ortalama $6.5 \mathrm{~g}$ civarı olan balıklar deneme sonu itibari ile ortalama 26 g ağırlığına ç1kmış olup en çok büyüme kontrol grubunda görünmüştür (Çizelge 4). Büyüme parametreleri bakımından genellikle $\mathrm{D}_{0}, \mathrm{D}_{1}, \mathrm{D}_{2}$ grupları birbirine benzerken $(\mathrm{P}>0.05)$ bu gruplar diğer gruplardan $\left(\mathrm{D}_{3}\right.$, $\left.\mathrm{D}_{4}\right)$ farklı bulunmuştur $(\mathrm{P}<0.05)$ (Çizelge 4$)$.

Balık unu yerine rasyona $\% 20$ 'den fazla gülibrişim (Albizia julibrissin) tohumu eklendiğinde koi sazanlarındaki büyüme parametrelerini olumsuz etkilemiştir. Bu besin ve enerji kullanımındaki azalma, proteinin etkin bir şekilde kullanılmaması gibi faktörlerden kaynaklanmış olabileceği gibi bu diyetlerde bir veya daha fazla aminoasit eksikliğinden kaynaklanmış olabilir. Benzer sonuçları Borlongan ve ark (2003) tarafindan da rapor edilmiştir.

Balık beslemede kullanılan bitkisel protein kaynakları hayvansal protein kaynaklarına göre aminoasit bakımından fakirdir (Akness ve ark., 2008). $\mathrm{Bu}$ eksikliği gidermek için diyetler hazırlanırken koi sazanının ihtiyaç duyduğu esansiyel aminoasit gereksinimi (Hossain ve ark., 2002) göz önünde bulundurularak özellikle balık gelişiminde önemli rol oynayan methionin ve lysine katılarak rasyonlar esansiyel aminoasit bakımından yeterli seviyeye getirilmiştir. Buna karşın bitkisel protein kaynaklarında esansiyel olmayan aminoasitlerden hidroksiprolin ve taurin çok az ya da hiç bulunmamaktadır. Bu aminoasitler daha çok balık unu gibi hayvansal protein kaynaklarında yeterli miktarda bulunmaktadırlar (Akness ve ark., 2008; Chatzifotis ve ark., 2008). Aynı eksikliğin gülibrişim (Albizia julibrissin) tohumu içinde geçerli oluğu düşünülebilir.

Bitkisel protein kaynakları oligosakkaridler, fitaz, tanin ve tripsin inhibitörü gibi anti besinsel faktörler içerirler. Bu anti besinsel faktörler bitkisel proteinlerin balık unu ve diğer proteinlerin yerine balık diyetlerinde kullanılmasını sınırlandırır (Tacon, 1997). Özellikle de diyetlere yüksek oranda bitkisel kökenli protein kaynağının katılması, bu faktörlerin devreye girerek diyetlerde bulunan esansiyel aminoasitlerin emilimini azaltmasına neden olabilmektedir (Adebayo ve ark., 2004).
Bitkisel protein kaynaklarında bulunan anti besinsel faktörlerden tripsin inhibitör (TI) ve lektin bitkiler aleminin birçok üyesinde, baklagiller ve tahılda bulunmaktadır (Francis ve Parkinson, 2001). Bunların balıklar çizerindeki biyolojik etkileri, bağırsak metabolizmasının bozulması ve ince bağırsağın morfolojik yapısının bozulması olarak sıralanabilir. Tohumlarda bulunan bu faktörlerin elimine edilebilmesi için tohumun ya 1sitılması ya da otoklavda bekletilmesi gerekmektedir (Grant, 1991). Parmak boy sazanların (Cyprinus carpio) beslenme diyetlerine 1sıtılmış ve 1sıtılmamış culban (Vicia peregrina) alternatif protein kaynağ1 olarak belirli miktarlarda katılarak büyüme parametreleri araştırılmıştır. Culban diyetlere ham şekilde en fazla \%10 oranında katılabileceği saplanırken bu oran 1sıtılmış culban için \%20 olarak rapor edilmiştir (Büyükçapar ve Kamalak, 2006). Aynalı sazan yavrularının diyetlerine ham ve 1sıtılmış olarak yabani bezelyenin (Pisum elatius)'nin katıldığı çalışmada, rasyona bezelye $\% 10$ ham olarak katılabilirken 1sıtıldığında bu oran \%30'a çıktığı rapor edilmiştir (Büyükçapar ve Kamalak, 2010). Gülibrişim (Albizia julibrissin) rasyona katılım oranı artırabilmek için 1sıl işlem kullanılabilir.

Gülibrişim (Albizia julibrissin) tohumu koi sazanlarının diyetlerinde kullanılabilecek alternatif bir protein kaynağı olup, \%20'ye kadar kullanılmasında balıklarda büyüme açısından herhangi bir sakınca yaratmamaktadır. Gülibrişim (Albizia julibrissin) tohumu kolay ve ucuz olarak elde edilebilmesi nedeniyle koi sazanı yavrularının diyetlerinde kullanılabilecek alternatif protein kaynaklarından biri olarak nitelendirilebilir.

\section{SONUC}

Yapılan çalışmada kullanılan gülibrişim (Albizia julibrissin) tohumu bölgedeki park, bahçe ve arazilerde bol miktarda bulunmaktadır. Elde edilmesi kolay ve masrafsız olan gülibrişim (Albizia julibrissin) tohumu ununun sazan yemlerinde daha yaygin kullanılması yem maliyetinin düşürülmesinde katkı sağlayabilir aynı zamanda yapılan çalışmada diyetlere \%20'den fazla ham gülibrişim (Albizia julibrissin) tohumu unun eklenmesi büyüme parametrelerini olumsuz etkilemiştir. Rasyona katılabilir doz \%20 olup bu doza kadar 
büyümeyi etkileyen hiçbir olumsuz gelişme gözlenmemiştir. Bitkisel protein kaynaklarının rasyona katılması aminoasit kompozisyonunu olumsuz etkileyebilir bunun için rasyon hazırlanırken balık türüne göre gerektiğinde rasyona aminoasit ilavesi yapilmalıdır.

\section{KAYNAKLAR}

Ahmed, M.M.M., El-Hag, F.M, 2004. Degradation Characteristics of Some Sudanese for Ages and Tree Pods Using in Sacco and Gas Production Technique. Small Ruminant Research, 54:147-156.

Akiyama, T., Munuma, T., Yamamoto, T., Marcouli, P., Kishi, S. 1995. Combinational use of Malt Protein Flour and Soybean Meal as Alternative Protein Sources of Fingerling Rainbow Trout Diets. Fisheries Science, 61(5): 825-832

AOAC, 1990. Oficial Methods of Analysis (15th ed.) Association of Official Analytical Chemists, Washington DC, USA. Pp.69-88.

Adebayo, O.T., Fagbenro, O.A., Jedege, T. 2004. Evaluation Of Cassia Fisculata Meal as A Replacement for Soybean Meal in Practical Diets of (Oreochromis niloticus) Fingerlings. Aquaculture Nutr. 10:99-104.

Akness, A., Mundheim, H., T Oppe, J., Albrektsen, S. 2008. The Effect of dietary Hydroxiproline Supplenentation on Solman (Salmo Solar l.) Fed High Plantprotein Diets. Aquaculture, 275: 242-249.

Borlongan, I. G., Eusebio, P. S., Welsh, T. 2003. Potential of feed pea (Pisum sativum) meal as a protein source in practical diets for milkfish (Chanos chanos Forsskal). Aquaculture, 225 (1-4), 89-98.

Büyükçapar, H.M., Kamalak, A. 2006. Partial Replacement of Fish and Soyabean Meal Protein in Mirror Carp (Cyprinus carpio) Diets by Protein in Hazelnut Meal. South African Journal of Animal Science, 37(1): 35-44.

Büyükçapar, H.M., Mezdegi, İ., Kamalak, A. 2010. Nutritive Value of Narbon Bean (Vicia narbonensis) Seed as Ingredients in Practical Diet for Tilapia (Oreochromis niloticus) Fingerlings. J. Appl. Anim. Res., 37:253-256.

Büyükçapar, H.M. Kamalak, A. 2010. Nutritive Value of Wild Pea (Pisum elatius) Seeds as Dietary Protein Source for Mirror Carp, (Cyprinus carpio). Fingerlings. Israeli Journal of Aquaculture Bamidgeh, 62(4): 272-280.

Büyükçapar, H.M., 2012. Growth Performance and Body Composition in Mirror Carp (Cyprinus carpio)
Fed Culban Seed (Vicia peregrina) With Different Heat Treatments. Kafkas Üniversitesi Veteriner Fakültesi Dergisi, 18 (3): 389-394.

Chatzifotis, S., Polemitou, I., Divanach, P., Antonopoulou, E. 2008. Effect of Dietary Taurine Supplementation on Growth Performence and Bile Salt Activated Lipase Activity of Common Dentex, Dentex dentex, Fed A Fish Meal/Soy Protein Concentrate-Based Diet. Aquaculture 275: 201-208.

Ertaş, N., 2007. Yemeklik Baklagiller ve Anti Besinsel Faktörler. Selçuk Üniversitesi, Ziraat Fakültesi Dergisi, 21 (41): 85-95.

Francis J.A, Parkinson, 2001. Replacement of Fish Meal in Diets for Australian Silver Perch, Bidyanus bidyanus V1. Effects of Dehulling and Protein Concentrationon Digestibility of Grain Legumes. Aquaculture, 196: 67-85.

Grant, G. 1991. Toxic Substances in Crop Plants. The Royal Society Of Chemistry, Thomas Graham House, Science Park, Cambridge Cb4 4wff, Cambridge, Pp. 49-67.

Hossain M.A. U. Fockbn And Becker, 2002. Nutritional Evaluation of Dhaincha (Sesbania aculeata) Seeds as Dietary Protein Source for Tilapia (Oreochromis niloticus) Aquaculture Research 33, 653-662.

NRC. 1993. Nutrient Requirements of Fish, National Research Council, 114 Pp. The National Academies Press, Washington

Overland, M., Storebakken, T., Penn, M., Kroghdel,A., Skrede, A. 2009. Pea Concentrate Substituting Fish Meal or Soybean Meal in Diets for Atlantic Salmon (Salmo salar)-Effect on Growth Performance, Nutrient Digestibility, Carcass Composition, Gut Health and Physical Feed Quality. Aquaculture, 288:305-311.

Pike, I.H., Barlow, S.M. 2003. Impact of Fish Farming on Fish Stocks. International Aquafeed Directory, 24-29.

Tacon, A.G.J. 1997. Fish Meal Replacers: Review of Antinutrients within Oilseed and Pulses. A Limiting Factor for The Aqua Feed Green Revolution? In: Feeding tommorrow's Fish. Eds. Tacon, A.G.J. and Basurco, B., Pp. 153-182. Cahiers Options Mediterraneennes. Instut Agronomique Mediterraneenne de Zaragoza, Spain.

Ustaoğlu, S., Karayücel, İ., Alagil, F., Dernekbaşı, S., Yağc1, F. 2009. Evaluation of Extruded Chickpea, Common Bean and Red Lentil Meals as Protein Source in Diets for Juvenile Rainbow Trout (Oncorhynchus mykiss). Journal of Animal and Veterinary Advances, 8 (10):2079-2086. 